PSICOLOGIA,SAÚDE \& DOENÇAS, 2016, 17(3), 423-440

ISSN - 2182-8407

Sociedade Portuguesa de Psicologia da Saúde - SPPS - www.sp-ps.com

DOI: http://dx.doi.org/10.15309/16psd170310

\title{
PARENTAL CONCERNS DEFINITION: A LITERATURE REVIEW
}

\author{
Susana Algarvio ${ }^{1 \cong}$ \& Isabel Leal ${ }^{2}$ \\ ${ }^{1}$ ISPA-IU, 1149-041, Lisboa, Portugal; e-mail: susana.algarvio@ ispa.pt; ${ }^{2}$ ISPA-IU, 1149-041, Lisboa, Portugal; e- \\ mail::ileal@clix.pt
}

\begin{abstract}
Background: The evaluation of parental concerns is considered of extreme importance in clinical practice, confirmed by current research. However, criteria for the definition of parental concerns are not standardized, and reflect different levels of analysis. The purpose of this study was to build a descriptive literature base of the current research on parental concerns.

Methods: An extensive search was conducted using MEDLINE, ERIC, PsycINFO, PsycARTICLES, Academic Search Complete, Education Research Complete, PEP Archive, and Psychology and Behavioral Sciences Collection databases. The key words used were parental concerns. Criteria for inclusion were: peer-reviewed publications, parental concerns' assessment, issue of interest for general parenting.

Results: A total of 4130 publications were abstracted and reviewed, 128 were selected for inclusion. Themes from these papers were identified and were grouped according to seven main outcome categories: Parental concerns' definition, parental concerns' determinants, parental concerns predictive of children's problems, parental concerns predictive of parental behaviour, parental concerns' outcomes, parental concerns' influence on healthcare professionals, and parental concerns and intervention strategies. Conclusions: Evidence demonstrated that parental concerns are an expected and positive aspect of parenting. They influence parental behaviour and thus promote positive outcomes in children. Parental concerns presented high sensitivity regarding children's problems, being considered as effective as formal testing. General parental concerns, the factors that influence them and the related outcomes should be considered in future studies. Further research should also address the development of standardized instruments for the assessment of general parental concerns.
\end{abstract}

Key-words: Parenting; parental concerns; parental concerns definition; review of literature

\section{DEFINIÇÃO DE PREOCUPAÇÕES PARENTAIS: REVISÃO SISTEMÁTICA DE LITERATURA}

RESUMO: Objetivo: A avaliação das preocupações parentais é considerada fundamental na prática clínica, aspeto confirmado na literatura. No entanto, os critérios para a definição de preocupações parentais não se encontram bem definidos e refletem diferentes níveis de análise. Este estudo tem como objetivo organizar uma base descritiva da literatura existente sobre preocupações parentais.

\footnotetext{
ڤ." Rua Jardim do Tabaco, nº 34, 1149-041 Lisboa; Telf.: 96505 56 56; e-mail: susana.algarvio@ispa.pt
} 


\section{PARENTAL CONCERNS DEFINITION}

Método: Foi realizada uma pesquisa com a palavra-chave parental concerns nas bases de dados MEDLINE, ERIC, PsycINFO, PsycARTICLES, Academic Search Complete, Education Research Complete, PEP Archive, and Psychology and Behavioral Sciences Collection. Os critérios para inclusão foram os seguintes: publicações com arbitragem científica, avaliação de preocupações parentais e, assunto de interesse para a parentalidade genérica.

Resultados: Foram selecionados 128 artigos de um total de 4130. Os artigos foram agrupados em 7 categorias, a partir dos temas identificados: Definição de preocupações parentais, determinantes de preocupações parentais, preocupações parentais preditivas de problemas das crianças, preocupações parentais preditivas do comportamento parental, resultado de preocupações parentais, influência das preocupações parentais nos técnicos de saúde e preocupações parentais e estratégias de intervenção.

Conclusões: Os resultados da investigação demonstram que as preocupações parentais são um aspeto esperado e positivo da parentalidade. Influenciam o comportamento parental, promovendo resultados positivos no desenvolvimento infantil. Apresentam uma elevada sensibilidade relativamente aos problemas das crianças, sendo tão eficazes como um teste de avaliação. Estudos futuros deverão centrar-se nas preocupações parentais genéricas, nos seus fatores de influência, nos seus resultados, e no desenvolvimento de instrumentos de medida de avaliação das preocupações parentais.

Palavras-chave: Parentalidade; preocupações parentais; definição preocupações parentais; revisão de literatura

Recebido em 15 de Outubro de 2014/ Aceite em 12 de Novembro de 2016

There is an extensive body of research concerning the identification of parental concerns regarding specific groups of parents, determined medical conditions, educational issues, or different children's problems. The importance of addressing parental concerns is also well documented; however, as a result of the vast scientific production in this area, criteria for defining parental concern are not standardized. Some studies considered what parents expressed as their concerns, and others, what researchers considered to be cause for concern based on the literature.

Few studies explored parental concerns in the general population, concerning normative parenting. Stickler et al. (1991) compared parental worries to actual medical and social risks. They concluded that the majority of parents focused their concerns on good parenting, systematized in providing their children with appropriate discipline, affection, good values and morals, and about providing sufficient financial support for their families. Their results also pointed to some issues causing disproportionate anxiety comparing to real risks, such as the abduction of the child, representing the highest percentage of frequent worries expressed by the parents who participated in the study.

A longitudinal study was conducted by Mesibov et al. (1993) in a paediatric setting, with parents from middle socioeconomic class. Results indicated that negative behaviours were the most frequent cause for concern and that there were certain ages (2-3 years old) that caused more concern in parents.

Blanchard et al. (2006) using data from the 2003 National Survey of Children's Health, with 102,353 children from the United States, reported rates of parental concerns about emotional, developmental, or behavioural problems much higher than the rates of children that were actually diagnosed with those problems. 
A more recent study was conducted in the Netherlands (Reijneveld et al., 2008) with a representative sample of 4107 parents, to assess the prevalence of parental concerns about their child's development and also to identify risk groups. The results obtained showed that $49.3 \%$ of the parents reported some concerns, and $8.7 \%$ reported frequent concerns, mostly concerning child behaviour. The prevalence rates of professional-assessed parenting problems were much lower than those reported by the parents. They concluded that, considering the high prevalence rates obtained, parental concerns must be a general aspect of parenting.

Slater et al. (2010) identified parents' concerns in 1202 Australian parents of children from 2 to 16 years old. Parents were mostly concerned about their child's education (35\%), child's health and well-being (25\%) and violence, drugs and alcohol (20\%). Despite aiming at the children's diet, activity habits and weight status, this study did provide additional information about normative parenting.

\section{METHODS}

An extensive search was conducted using several databases: MEDLINE, ERIC, PsycINFO, PsycARTICLES, Academic Search Complete, Education Research Complete, PEP Archive, and Psychology and Behavioral Sciences Collection. The key words used were parental concerns. Criteria for inclusion were: peer-reviewed publications, parental concerns' assessment, issue of interest for general parenting.

\section{RESULTS}

A total of 4130 publications were abstracted and reviewed, 128 were selected for inclusion. Themes from these papers were identified, and were grouped, according to seven main outcome categories: Parental concerns' definition, parental concerns' determinants, parental concerns predictive of children's problems, parental concerns predictive of parental behaviour, parental concerns' outcomes, parental concerns' influence on healthcare professionals, parental concerns and intervention strategies. Another theme was identified but it was not selected for inclusion: the identification of parental concerns under determined health, educational and social circumstances, because of its specificity on the parenting process.

\section{Parental concerns definition}

According to Mesibov et al. (1993), most studies defined parental concerns by how frequently a paediatrician makes a referral of a parent with a specific concern to a psychologist, social worker or psychiatrist.

Winnicott (1979) considered that the capacity for concern is acquired when the individual reaches a level of emotional maturity where he/she cares, feels, and accepts responsibility for the other. It is generally accepted that parental concern is characterized by sympathy, care for the child (Fouladi et al., 2006; Huppertz et. al., 2008; Kloep et al., 2001), more specifically, by a preoccupation with the interests and wants of the child, which was also verified in neuropsychological studies (Swain et al., 2007). This concern can be expressed as protection, involvement, support and encouragement (Fouladi et. al., 2006) or even as anger when the child presents destructive tendencies that put his/her development at risk (Likierman, 1987). 


\section{PARENTAL CONCERNS DEFINITION}

Parental concerns may address child-related concerns, and/or parent-related concerns, defined as job stress, and personal concerns (Duhig et al., 2002; Greenberger \& O’Neil, 1990). Accordingly, Dix $(1991$; 1992) conceptualized parental concerns related to parental goals, organized into childcentred goals, and parent-centred goals. He further refers that effective parenting must have childcentred goals, even though parents' concerns must be considered in positive parenting. Parenting evolves organizing emotions empathically around concerns and outcomes necessary to the child's well-being and development. Additionally, this parental emotional awareness will promote the attendance to the child's needs, the willingness to teach, to encourage and to comfort.

\section{Parental concerns' determinants}

Parental concerns usually express actual problems being experienced by the child, but evidence has reported different influence factors. Therefore, parental concerns may be influenced by internal factors, like parents' personality characteristics (Demby, 2009; Matthey, 2001; Wildman et al., 2004), parental cognitions (Sadeh et al., 2007), parental separation anxiety (Kaitz, 2007; Sadeh et. al., 2007), and parents' mental health problems (Briggs-Gowan et al., 1996; Dix, 1992; Swain et al., 2007).

Several studies supported evidence for external factors influencing parental concerns, related to the child, such as difficult temperament or behaviour (Ellingson et al., 2004; Kaitz, 2007; Owens \& Palermo, 2008), or related to the parents, such as family stress, resulting from recent divorce (Campbell \& Johnston, 1986; Hodges et al., 1990), family violence (Wissow et al., 1992), poverty and chronic stress (Richter, 2003), and also job stress (Kaitz, 2007; Barnett et al., 2010).

Mothers that have experienced obstetrical complications also presented contiguity of concerns overtime (Kaitz, 2007). Negative events may diminish the parents' ability to differentiate their children's needs from their own, and consequently the possibility to protect and care for their child (Campbell \& Johnston, 1986; Dix, 1992).

Concerning the effects of demographic factors on parental concerns, Glascoe et al. $(1989 ; 1995)$ did not obtain significant differences for the type of concerns parents raised, as well as for their accuracy. However, Reijneveld et al. (2008) reported that frequent concerns were more prevalent among parents of young children, of labour-immigrant origin, with low family income and a medium paternal educational level.

\section{Parental concerns predictive of children's problems}

Glascoe et col. $(1989 ; 1991 ; 1994 ; 1995 ; 1997 ; 1999 ; 2003)$ conducted an extensive research about the importance of using parental concerns as an indicator of children's developmental and behavioural problems. These studies allowed the development of a well standardized instrument to elicit parental concerns, named Parents' Evaluation of Developmental Status, and also provided evidence that parental concerns were highly predictive of behavioural and developmental problems in children.

Several studies provided evidence for parents' concerns high sensitivity in identifying developmental delays in children. Parents' concerns for speech, language, motor, or cognitive skills were indicators of developmental delay (Coghlan et al., 2004; Chung et al., 2011; Diamond, 1993; Glascoe et al., 1989; Glascoe, 1991; McGinty, 2000; Samms-Vaughan \& Franklyn-Banton, 2008). However, parental concerns about cognitive problems, global delay, or associated behavioural concerns presented lower sensitivity for developmental delay (Chen et al., 2004; Chen et al., 2007; Chung et al., 2011; Glascoe \& Dworkin, 1995). Parental concerns about behaviour, emotions, and/or language were often indicators of developmental delays rather than behavioural delays 
(Glascoe, 1994; Oberklaid et al., 1979). In addition, Reijneveld et al. (2008) verified that professional and parent agreement varied from $73.8 \%$ in behavioural problems, to $87.5 \%$ in developmental delays.

High sensitivity was also obtained in identifying children's behavioural problems, although the positive predictive value was low because parents voiced more concerns than the children had significant problems (Glascoe et al., 1991; Malhi \& Singhi, 2002; Mulhern et al., 1994). A similar result was obtained with hearing concerns (Hammond et al., 1997) and in the study by Stickler et al. (1991) where parental concerns were much higher than the actual risks the child was facing.

Furthermore, parental concerns voiced in early childhood significantly predicted school-age problems (Briggs-Gowan \& Carter, 2008; Diamond, 1987; Restall \& Borton, 2010), and identified a large number of children with hearing loss (Olusanya et al., 2006; Thompson \& Thompson, 1991).

Ford et al. (2005) conducted a nationally representative study in Great Britain, with 10438 children aged from 5 to 15 years, addressing parental concerns about their children's emotions and behaviour. Results from this study confirmed that clinicians should rely on the lack of parental concern about the presence of psychiatric disorders in the child. Parents were accurate at identifying conduct disorders, and positive predictive power increased when both the parent and the teacher were concerned.

Specificity was found to be high in all the studies considered (Drachler et al., 2005; Ford et al., 2005; Glascoe, 1997), addressing American, Brazilian, and British, populations of parents. However, in the Brazilian results pointed to a $99.5 \%$ of negative predictive value for the wealthier and higher educated mothers, while for deprived mothers, $5 \%$ of the children considered to have a normal development by their parents obtained a score reflecting a developmental delay. Even though the authors considered a lower predictive value for this population, it still maintained a high positive predictive value of $95 \%$.

Concerning chronic diseases, Kulkarni (2007) found that for the majority of parents with hydrocephalus, their concerns fairly reflected the status of their child. Wren et al. (2003) conducted a large study about child's psychosocial problems, with 395 clinicians and 20861 children aged between 4-15 years. They verified that parental concerns about mood and anxiety symptoms were not predictors of psychosocial problems.

Concern is considered excessive when parents report concern about children's problems that are not confirmed by a professional assessment. Nevertheless, it may reflect an underdiagnosis, representing a more sensitive observation from parents that should be further investigated by clinicians (Diamond, 1993; Glascoe, 1991; Glascoe, 1997; McMahon et al., 2007). Glascoe et al. (1991) found that parents concerns which were not confirmed by a behavioral screening, had children with more behavioural problems than those parents who did not have any concerns.

\section{Parental concerns predictive of parental behaviour}

Dix (1992) considered that parents engage in determined behaviours once they have defined a particular goal concerning their children. Parental concerns over the negative effects of television were significant predictors of the television mediation style (Valkenburg et al., 1999), as well as parental safety concerns predicted the use of a car to take children to school (Ridgewell et al., 2009). These parental concerns were also associated with being proactive in mothers of children with disabilities (Vaughan, 2005); they were considered fundamental to the fathers' involvement in families with children with haemophilia, and therefore also important for the family's success in concerning their coping strategies (Mattsson \& Gross, 1966); and were likely to promote healthier practices in overweight or obese children (Lampard et al., 2008). Parental concerns were also 


\section{PARENTAL CONCERNS DEFINITION}

reported as a factor that predicts the seek for help/advice about their child's communication development (Skeat et al., 2010).

Parental concerns may also promote a controlling behaviour, or restrictive parenting practices. They may stimulate a controlling parenting through dependency, related to parental separation anxiety, and achievement, which, in turn, is related to perfectionism (Baptiste, 2005; Soenens et al., 2010). Parental concerns expressed by anxiety for the child, associated with feelings of exhaustion and excessive stress, were related to restrictive practices and controlling behaviour in sick children (Huppertz et al., 2008).

The concern about fever and its potential harm was related to excessive monitoring and treatment of children, which might be felt by them as intrusive (Crocetti et al., 2001). Moreover, parents with greater concern about medication for asthma were more likely to have poor adherence to the children's treatment (Chan \& DeBruyne, 2000; Conn, et al. 2005). Similar results were found for parents of children with $\mathrm{ADHD}$, in spite of parents having felt that they were given adequate information about medication's safety (Kiliç et al., 2007; Stine, 1994). Greater parental concern is also associated to reduced uptake of vaccination (Fredrickson et al., 2004; Petousis-Harris et al., 2004), especially in better educated families (Leib et al., 2011).

Excessive parental concern about child's development, or behaviour, predicted significant levels of parenting stress, but did not influence the parents' decision to seek for medical care for their children with mild acute illnesses (Voigt et al., 2009).

\section{Parental concerns' outcomes}

The preoccupation with the child's needs allows the formation of strong interpersonal bonds (Swain et al., 2007), and it is predictive of positive outcomes for childhood and adolescence behaviour. It was found to be predictive of less addictive behaviours in adolescence (Kalesan et al., 2006; Kloep et al., 2001), of adolescent's life satisfaction associated with academic competence (Leung et al., 2004), and of children and adolescent's achievement and academic success (Duchesne $\&$ Ratelle, 2010). When genuine concern about others' activities is expressed at mealtime, children are less likely to experience internalizing symptoms (Fiese et al., 2006). Greater parental concern and involvement are likely to encourage more active monitoring and controlling of a child's dietary intake, a greater inclination to seek treatment for an overweight child, and improved behavioural treatment outcomes for childhood obesity (Lampard et al., 2008).

Considering parental concern as parental care for the child, the absence of concern may reflect low patterns of parental care. Absence of the father's concern was correlated with child's personality problems (Peterson et al., 1959). Lack of parental concern about the infant's mental and physical development, was associated with mother's substance abuse during pregnancy (Seagull et al., 1996). Furthermore, a lack of parental concern in association with high levels of protection was related with greater internalizing symptoms (Anhalt \& Morris, 2008), and with smoking in adolescence (Distefan et al., 1998).

Research concerning childhood obesity reported that parents' low recognition rates of child's overweight or obesity, associated to a lack of parental concern (Bossink-Tuna et al., 2009; Lampard et al., 2008), particularly at school entry (Wake et al., 2008) may prevent parents from implementing strategies to diminish risk factors for childhood obesity (Crawford et al., 2006).

A greater parental concern over the child's weight may lead to a controlling behaviour, overprotection and restrictive practices regarding the child's eating habits (Musher-Eizenman et al., 2007), which may increase the risk of adolescent overweight (Haines et al., 2007); also, this type of behaviour was found to be associated with negative self-evaluations among girls (Davison \& Birch, 2001), and even growth failure in infants (Birch, 1990). Nevertheless, maternal concern about 
overweight when the child was 4 years old was not associated with the child's body dissatisfaction by the age of 6.5 (Mitchell et al., 2008). Perceptions of parental concerns were predictors of higher eating disorder scores in children between 6 and 14 years old (Gardner et al., 2000). Children's overweight was considered a risk factor for psychosocial problems, when associated to excessive parental concern (Stradmeijer et al., 2000).

Additionally, with participants with eating disorders, both preoccupation and parental interference were significantly (and positively) correlated with depression scores (Miljkovitch et al., 2005). In a study with 4,746 adolescents, from a population-based study about eating patterns and weight concerns among teenagers in the United States, greater parental concern was associated with steroid use, which was also associated with poorer self-esteem and higher rates of depressed mood and attempted suicide (Irving et al., 2002)

Parental concerns associated to controlling parenting, and restrictions, influence negatively the development of social competences and independence in children. Parental concerns were related to low social competences in transplant children (Törnqvist et al., 1999), to changes in sleep arrangements caused by parental separation anxiety in children with epilepsy (Williams et al., 2000), and to less time playing outdoors in primary school children (Bringolf-Isler et al., 2010), which in turn may indirectly influence overweight and obesity, among children (Timperio et al., 2005). Another study suggests that parents that were concerned about their children's activity level provided a less supportive environment for physical activity, and therefore, their children were less active than those of parents that were not concerned (Jackson et al., 2008).

Greater parental concern was also associated with more frequent parental report of internalizing behaviour problems of their children (Bos et al., 2007). Furthermore, when parental concerns were related to perfectionism, they may compromise the chances of academic success (Duchesne \& Ratelle, 2010).

\section{Parental concerns' influence on healthcare professionals}

Parental concerns may influence medical decisions, even when the procedure is contrary to their initial judgement. Parental concerns influenced paediatric dentists (Zimmerman et al., 2009), dermatologists' decisions to remove benign skin lesions (Lucas et. al, 2007), and otolaryngologists' decisions to insert tubes (McIsaac et al., 2000). In certain situations, parental concerns led clinicians to excessive testing and inadequate therapy (Davids et al., 1993; Edwards et al., 1994).

Parental concern and the severity of the child's illness were considered to be more important than social circumstances, in determining referral from general practitioners to specialist services, concerning psychiatric disorders in children (Chithiramohan et al., 1993). In another study, the majority of general practitioners made their referral to tertiary neurodisability, responding to parental concerns, in the absence of a medical diagnosis (Dale \& Godsman, 2000).

Dulcan et al. (1990) verified that parental anxiety or depressive symptoms influenced paediatricians' identification of psychiatric problems in children. In addition, physicians are more likely to identify children's psychiatric and/or psychosocial problems and make referrals for intervention when parents openly voice their concerns about their children (Dulcan et al., 1990; Lynch et al., 1997; Wildman et al., 1999).

A study reported that more paediatricians considered their job less satisfying (46\%), compared with physicians (21\%), because of parental vaccine concerns (Kempe et al., 2011). 


\section{PARENTAL CONCERNS DEFINITION}

\section{Parental concerns and intervention strategies}

Research provided evidence of parental concerns accuracy compared with formal testing. They provide multiple advantages to health professionals, such as, being easy to elicit, taking few professional time, and providing a collaborative approach. The eliciting of parental concerns allows the clinician to decide the type of intervention the parents' and or the child need: the promotion of normal development, reassurance, referral, or routine monitoring (Glascoe, 1999). The information about the source, and the intensity, of parental concerns may also be helpful to better understand the concern parents report (Diamond, 1993; Lampard et al., 2008).

In spite of parents being considered reliable sources of information, some studies concluded that parents thought that health professionals failed to listen to their concerns (Restall \& Borton, 2010), or adopted a "wait and see" approach, in speech and language delays (Lindsay \& Dockrell 2004; Rannard et al., 2005), in developmental delays (Restall \& Borton, 2010; Shevell et al., 2001), and in constipation (Farrell et al., 2003), which caused parental dissatisfaction. One of the major determinants of parental satisfaction with healthcare providers was the professional understanding of parental concerns, associated to directness, good communication, and receiving information (Hasnat \& Graves, 2000; Restall \& Borton, 2010). Even when the clinical impact of the problem is considered to be minor by the professional, parents need to perceive that their concerns are taken seriously (Farrell et al., 2003).

However, it was also found that there were parents who reported high levels of concern about enuresis (Inan et al., 2008), constipation (Inan et al., 2007), and behavioural problems (Ellingson et al., 2004; Glascoe, 1999), but did not voice their concerns to professionals. Studies addressing reasons why parents do not seek for professional assistance concluded that not knowing an appropriate care provider (Fujiwara et al., 2011), as well as confidence that the problem will resolve itself, difficulties experienced in asking for help, and the inability to judge the severity of children's problems, were the most frequent reasons mentioned (Barbarin, 2007; Reijneveld et al., 2008). Moreover, according to Glascoe (1999), parents thought that if their children's problems were significant, professionals would detect them on their own.

Reijneveld et al. (2008) analyzed sociodemographic factors that could influence the help seeking process, and verified that labour immigrant families (62\%), fathers with low (34\%) or unknown (33\%) educational level, income below poverty level (38\%) or unknown (41\%), and children aged between 7 and 12 years (36\%), reported higher rates of not seeking help, in spite of presenting significant concerns.

Facing the difficulty of some parents to seek professional help, despite their high levels of parental concern, professionals should elicit their concerns using screening measures that rely on parental reports (Ellingson et al., 2004; Glascoe, 1999). According to Glascoe and Dworkin (1995) parental concerns and well standardized parent report measures should be used in combination and constitute an effective method for the early detection of behavioural and developmental problems in primary-care settings. Additionally, parents reported more concerns when a checklist was used than when they were asked to voice their own concerns (Kanoy \& Schroeder, 1993; Triggs \& Perrin, 1989). Similarly, when paediatricians used a checklist a higher number of concerns were discussed with parents (Triggs \& Perrin, 1989). Regalado and Halfon (2001) reported that the use of validated approaches for the assessment of parental concerns and psychosocial risk factors seem to be more accurate in identifying developmental problems than clinicians' appraisals.

Considering the low positive predictive value of parental concerns, the referral based only on parental concerns would implicate excessive over-referral rates. According to Ford et al. (2005), when parents express concern about behavioural problems, they should be asked if the teacher is also concerned, which was reported as being more predictive of children's problems. For those 
parents that present unvalidated concerns, professionals are advised to make additional assessments before deciding if children should be referred or if parents should receive in-office counselling (Glascoe, 1997; Glascoe et al., 1991). Additionally, there is evidence to support that those parents who present unvalidated concerns are highly likely to respond quickly to early intervention (Glascoe \& Dworkin, 1995).

In spite of the influence of parents' mental health problems on parental concerns, or other factors causing excessive concern, it is more likely that those parents will also have children with problems. According to Glascoe and Dworkin (1995), when parents are distressed and express concerns about their children, they are more likely to provide accurate clinical information. However, professionals should intervene differently, addressing parental concerns about their children, but also recommending health or social services for parents (Kulkarni, 2007).

Regarding adherence to treatment, studies reported that when parents concerns are heard and discussed, they are more likely to comply with the child's medical treatment (Chambers et al., 1997; Cuffwright, 2008; Fredrickson et al., 2004; Huang et al., 2001). Although parental concerns were associated to a lack of knowledge, there is evidence that it is not sufficient to educate and inform parents in order to achieve changes in their behaviour, or even to decrease parental concerns (Chan \& DeBruyne, 2000; Franck et al., 2004; Huang et al., 2001; Stine, 1994). Therefore, it is fundamental to encourage parents to verbalize, rather than act, the concerns that may lead to nonadherence to the medical treatments (Sadeh et al., 2007; Stine, 1994). Blanchard et al. (2006) suggested a change from a focus on a child's developmental and behavioural problems, to one that takes into account the influence of these problems on the family.

In spite of considering that effective parenting must be centred on the needs of the child, a professional focus on parental concerns, rather than on concerns about the child, may present an opportunity to express feelings, to offer care and encouragement that can then be used with the child. A study addressing the involvement of fathers in therapy, verified that both parents responded well to being offered extra therapy sessions that focus on their own personal concerns (Duhig et al., 2002).

Considering that parental concerns expressed by parents to healthcare professionals are mostly related to normal child development, parent education programs should include a multidisciplinary team, concerning multidisciplinary settings, specific children's ages, and childrearing problems (Mesibov et al., 1993). A multidisciplinary team will also be helpful to the help seeking process, by orienting parents to the appropriate care provider, and assisting with care coordination (Restall \& Borton, 2010). Furthermore, active listening skills to understand parental concerns are supportive to parents, and may result in benefits to the parents-child relationship (Tomlin, 2003).

\section{DISCUSSION}

Overall, evidence supports the fact that parental concerns are an expected and positive aspect of parenting. Parents' concerns about different aspects of parenting are highly prevalent in the general population, and are predictors of positive outcomes in children. Additionally, research reported that parental concerns should be considered as effective as formal testing because they were found to be highly sensitive to certain children's problems.

Parents need to perceive that their concerns are taken seriously by professionals, factor that promotes satisfaction with healthcare services, and may even prevent mental health disorders in children. Therefore, listening, and eliciting parental concerns are major issues in preventive healthcare, in the diagnostic process, and in the children's treatment. 


\section{PARENTAL CONCERNS DEFINITION}

Nevertheless, there are factors that might influence parental concerns, and also their possibility of being voiced, that could adversely affect parent-child relationships. Excessive concern or lack of concern may have an effect on parents' behaviour that will affect the child's well-being.

General parental concerns should be further studied, as well as the factors that predict lower or higher levels of parental concern, and that may be a risk factor for children's physical and mental health problems. Further research should also address the development of standardized instruments for the assessment of general parental concerns and the difficulties the healthcare professionals face when communicating with parents and their children about parental concerns.

Key messages

- Parental concerns are a positive aspect of parenting and are predictive of children's problems

- Excessive parental concern or lack of concern may have an adverse effect on the child's wellbeing

- Parental concerns should be addressed by health professionals

- Professionals should improve their skills/abilities to better communicate with parents

- Instruments must be developed to elicit parental concerns

\section{FUNDING}

This work was supported by Programa Operacional da Ciência e Inovação 2010, the Portuguese Government and European Social Fund (PhD grant SFRH/BD/ 32206/2006)

\section{REFERENCES}

Anhalt, K., \& Morris, T. L. (2008). Parenting characteristics associated with anxiety and depression: a multivariate approach. Journal of Early \& Intensive Behavior Intervention, 5(3), 122-137.

Baptiste, D. (2005). Family therapy with East Indian immigrant parents rearing children in the United States: Parental concerns, therapeutic issues, and recommendations. Contemporary Family Therapy: An International Journal, 27(3), 345-366. doi:10.1007/s10591-005-6214-9

Barbarin, O. (2007). Mental health screening of preschool children: Validity and reliability of ABLE. American Journal of Orthopsychiatry, 77(3), 402-418. doi:10.1037/00029432.77.3.402

Barnett, R., Gareis, K., Sabattini, L., \& Carter, N. (2010). Parental concerns about after-school time: Antecedents and correlates among dual-earner parents. Journal of Family Issues, 31(5), 606625. doi:10.1177/0192513X09353019

Birch, L. L. (1990). Development of food acceptance patterns. Developmental Psychology, 26(4), 515-519. doi:10.1037/0012-1649.26.4.515

Blanchard, L. T., Gurka, M. J., \& Blackman, J. A. (2006). Emotional, developmental, and behavioral health of American children and their families: a report from the 2003 National Survey of Children's Health. Pediatrics, 117(6), e1202-1212. doi:10.1542/peds.2005-2606 
Bos, H., van Balen, F., \& van den Boom, D. (2007). Child adjustment and parenting in planned lesbian-parent families. American Journal of Orthopsychiatry, 77(1), 38-48. doi:10.1037/0002-9432.77.1.38

Bossink-Tuna, H. N., L’Hoir, M. P., Beltman, M., \& Boere-Boonekamp, M. M. (2009). Parental perception of weight and weight-related behaviour in 2- to 4-year-old children in the eastern part of the Netherlands. European Journal of Pediatrics, 168(3), 333-339. doi:10.1007/s00431-008-0787-x

Briggs-Gowan, M., Carter, A., Schwab-Stone, M. (1996). Discrepancies among mother, child, and teacher reports: examining the contributions of maternal depression and anxiety. Journal of Abnormal Child Psychology, 24(6), 749-765.

Briggs-Gowan, M., \& Carter, A. (2008). Social-emotional screening status in early childhood predicts elementary school outcomes. Pediatrics, 121(5), 957-962. doi:10.1542/peds.20071948

Bringolf-Isler, B., Grize, L., Mäder, U., Ruch, N., Sennhauser, F., \& Braun-Fahrländer, C. (2010). Built environment, parents' perception, and children's vigorous outdoor play. Preventive Medicine, 50(5/6), 251-256. doi:10.1016/j.ypmed.2010.03.008

Campbell, L., \& Johnston, J. (1986). Impasse-directed mediation with high conflict families in custody disputes. Behavioral Sciences \& the Law, 4(2), 217-241. doi:10.1002/bsl.2370040209

Chambers, C., Reid, G., McGrath, P., Finley, G., \& Ellerton, M. (1997). A randomized trial of a pain education booklet: Effects on parents' attitudes and postoperative pain management. Children's Health Care, 26(1), 1-13. doi:10.1207/s15326888chc2601_1

Chan, P., \& DeBruyne, J. (2000). Parental concern towards the use of inhaled therapy in children with chronic asthma. Pediatrics International, 42(5), 547-551. doi:10.1046/j.1442200x.2000.01278.x

Chen, I. C., Lee, H. C., Yeh, G. C, Lai, C. H., \& Chen, S. C. (2004). The relationship between parental concerns and professional assessment in developmental delay in infants and children: a hospital-based study. Journal of the Chinese Medical Association, 67(5), 239-244.

Chen, I. C., Lin, C. H., Wen, S. H., \& Wu, C. H. (2007). How effectively do parents discern their children's cognitive deficits at a preschool age? Journal of the Chinese Medical Association, 70 (10), 445-450. doi:10.1016/S1726-4901(08)70036-4

Chithiramohan, R. N., Ballard, C. G., Baxter, M. A., \& Jones, L. (1993). Factors influencing general practitioner referral to a child psychiatric service. Irish Journal of Psychological Medicine, 10(3), 144-147.

Chung, C.-Y., Liu, W.-Y., Chang, C.-J., Chen, C.-L., Tang, S.F.-T., \& Wong, A. M.-K. (2011). The relationship between parental concerns and final diagnosis in children with developmental delay. Journal of Child Neurology, 26(4), 413-419. doi:10.1177/0883073810381922

Coghlan, D., Kiing, J., \& Wake, M. (2003). Parents' Evaluation of Developmental Status in the Australian day-care setting: Developmental concerns of parents and carers. Journal of Paediatrics and Child Health, 39(1), 49-54. doi:10.1046/j.1440-1754.2003.00084.x

Conn, K. M., Halterman, J. S., Fisher, S. G., Yoos, H. L., Chin, N. P., \& Szilagyi, P. G. (2005). Parental beliefs about medications and medication adherence among urban children with asthma. Ambulatory Pediatrics, 5(5), 306-310. doi:10.1367/A05-004R1.1

Crawford, D., Timperio, A., Telford, A., \& Salmon, J. (2006). Parental concerns about childhood obesity and the strategies employed to prevent unhealthy weight gain in children. Public Health Nutrition, 9(7), 889-895. doi:10.1017/PHN2005917 


\section{PARENTAL CONCERNS DEFINITION}

Crocetti, M., Moghbeli, N., \& Serwint, J. (2001). Fever phobia revisited: Have parental misconceptions about fever changed in 20 years? Pediatrics, 107(6), 1241-1246. doi:10.1542/peds.107.6.1241

Cuffwright, M. (2008). Managing children with asthma. Practice Nurse, 36(5), 25-30.

Dale, N., \& Godsman, J. (2000). Factors influencing general practitioner referrals to a tertiary paediatric neurodisability service. The British Journal of General Practice, 50(451), 131-132.

Davids, J. R., Kolman, B. H., Billman, G. F., \& Krous, H. F. (1993). Subcutaneous granuloma annulare: recognition and treatment. Journal of Pediatric Orthopedics, 13(5), 582-586.

Davison, K., \& Birch, L. (2001). Weight status, parent reaction, and self-concept in five-year-old girls. Pediatrics, 107(1), 46-53. doi:10.1542/peds.107.1.46

Demby, S. (2009). Interparent hatred and its impact on parenting: Assessment in forensic custody evaluations. Psychoanalytic Inquiry, 29(6), 477-490. doi:10.1080/07351690903013959

Diamond, K. E. (1987). Predicting school problems from preschool developmental screening: a four-year follow-up of the revised Denver developmental screening test and role of parent report. Journal of Early Intervention, 11(3), 247-253. doi:10.1177/105381518701100307

Diamond, K. E. (1993). The role of parents' observations and concerns in screening for developmental delays in young children. Topics in Early Childhood Special Education, 13(1), 69-82. doi:10.1177/027112149301300108

Distefan, J. M., Gilpin, E. A., Choi, W. S., \& Pierce, J. P. (1998). Parental influences predict adolescent smoking in the United States, 1989-1993. Journal of Adolescent Health, 22(6), 466-474. doi:10.1016/S1054-139X(98)00013-5

Dix, T. (1991). The affective organization of parenting: Adaptive and maladaptative processes. Psychological Bulletin, 110(1), 3-25. doi:10.1037/0033-2909.110.1.3

Dix, T. (1992). Parenting on behalf of the child: Empathic goals in the regulation of responsive parenting. In I. Sigel, A. V. McGillicuddy-DeLisis, and J. J. Goodnow (eds.), Parental Belief Systems: Psychological Consequences for Children. Hillsdale, N.J.: Erlbaum.

Drachler, M., De Castro Aerts, D., De Souza, R., De Carvalho Leite, J., Giugliani, E., \& Marshall, T. (2005). Social inequalities in maternal opinion of child development in southern Brazil. Acta Paediatrica, 94(8), 1137-1139. doi:10.1080/08035250510036534.

Duchesne, S., \& Ratelle, C. (2010). Parental behaviors and adolescents' achievement goals at the beginning of middle school: Emotional problems as potential mediators. Journal of Educational Psychology, 102(2), 497-507. doi:10.1037/a0019320

Duhig, A., Phares, V., \& Birkeland, R. (2002). Involvement of fathers in therapy: A survey of clinicians. Professional Psychology: Research and Practice, 33(4), 389-395. doi:10.1037/0735-7028.33.4.389

Dulcan, M. K., Costello, E. J., Costello, A. J., Edelbrock, C., Brent, D. \& Janiszewski, S. (1990). The pediatrician as gatekeeper to mental health care for children: Do parents' concerns open the gate? Journal of the American Academy of Child \& Adolescent Psychiatry, 29(3), 453458. doi:10.1097/00004583-199005000-00018

Edwards, M. C., Mullins, L. L., Johnson, J., \& Bernardy, N. (1994). Survey of pediatricians' management practices for recurrent abdominal pain. Journal of Pediatric Psychology, 19(2), 241-253. doi:10.1093/jpepsy/19.2.241

Ellingson, K. D., Briggs-Gowan, M. J., Carter, A. S., \& Horwitz, S. M. (2004). Parent identification of early emerging child behavior problems: predictors of sharing parental concern with health providers. Archives of Pediatrics \& Adolescent Medicine, 158(8), 766-772. doi:10.1001/archpedi.158.8.766 
Farrell, M., Holmes, G., Coldicutt, P., \& Peak, M. (2003). Management of childhood constipation: parents' experiences. Journal of Advanced Nursing, 44(5), 479-489. doi:10.1046/j.03092402.2003.02831.x

Fiese, B., Foley, K., \& Spagnola, M. (2006). Routine and ritual elements in family mealtimes: Contexts for child well-being and family identity. New Directions for Child \& Adolescent Development, 111, 67-89. doi:10.1002/cad.155

Ford, T., Sayal, K., Meltzer, H., \& Goodman, R. (2005). Parental concerns about their child's emotions and behaviour and referral to specialist services: general population survey. British Medical Journal, 331(7530), 1435-1436. doi:10.1136/bmj.331.7530.1435

Fouladi, R., Moller, N., \& McCarthy, C. (2006). Examination of internal consistency and construct validity of scores on the Parental Attachment Scale: Preliminary psychometric results. Measurement \& Evaluation in Counseling \& Development, 39(1), 2-30.

Franck, L. S., Cox, S., Allen, A., \& Winter, I. (2004). Parental concern and distress about infant pain. Archives of Disease in Childhood - Fetal and Neonatal Edition, 89(1), F71-F75. doi:10.1136/fn.89.1.F71

Fredrickson, D. D., Davis, T. C., Arnould, C. L., Kennen, E. M., Hurniston, S. G., Cross, J. T., \& Bocchini, J. A. (2004). Childhood immunization refusal: provider and parent perceptions. Family Medicine, 36(6), 431-439.

Fujiwara, T., Okuyama, M., \& Funahashi, K. (2011). Factors influencing time lag between first parental concern and first visit to child psychiatric services in children with Autism Spectrum Disorders in Japan. Research in Autism Spectrum Disorders, 5(1), 584-591. doi:10.1016/j.rasd.2010.07.002

Gardner, R., Stark, K., Friedman, B., \& Jackson, N. (2000). Predictors of eating disorder scores in children ages 6 through 14: A longitudinal study. Journal of Psychosomatic Research, 49(3), 199-205. doi:10.1016/S0022-3999(00)00172-0.

Glascoe, F. P. (1991). Can clinical judgment detect children with speech-language problems? Pediatrics, 87(3), 317-322.

Glascoe, F. P. (1994). It's not what it seems: The relationship between parents' concerns and children's cognitive status. Clinical Pediatrics, 33(5), 292-296. doi:10.1177/000992289403300507

Glascoe, F. P. (1997). Parents' concerns about children's development: Prescreening technique or screening test? Pediatrics, 99(4), 522-528. doi:0.1542/peds.99.4.522

Glascoe, F. P. (1999). Using parents' concerns to detect and address developmental and behavioral problems. Journal of the Society of Pediatric Nurses, 4(1), 24-35. doi:10.1111/j.17446155.1999.tb00077.x

Glascoe, F. P. (2003). Parents' evaluation of developmental status: How well do parents' concerns identify children with behavioral and emotional problems? Clinical Pediatrics, 42(2), 133138. doi:10.1177/000992280304200206

Glascoe, F. P., Altemeier, W. A., \& MacLean, W. E. (1989). The importance of parents' concerns about their child's development. American Journal of Diseases of Children, 143, 955-958.

Glascoe, F. P., \& Dworkin, P. H. (1995). The role of parents in the detection of developmental and behavioral problems. Pediatrics, 95(6), 829-836.

Glascoe, F. P., MacLean, W. E., \& Stone, W. L. (1991). The importance of parents' concerns about their child's behavior. Clinical Pediatrics, 30(1), 8-11. doi:10.1177/000992289103000101

Greenberger, E., \& O'Neil, R. (1990). Parents' concerns about their child's development: Implications for fathers' and mothers' well-being and attitudes toward work. Journal of Marriage \& the Family, 52(3), 621-635. 


\section{PARENTAL CONCERNS DEFINITION}

Hammond, P. D., Gold, M. S., Wigg, N. R., \& Volkmer, R. E. (1997). Preschool hearing screening: evaluation of a parental questionnaire. Journal of Paediatrics and Child Health, 33(6), 528530. doi:10.1111/j.1440-1754.1997.tb01664.x

Haines, J., Neumark-Sztainer, D., Wall, M., \& Story, M. (2007). Personal, behavioral, and environmental risk and protective factors for adolescent overweight. Obesity, 15(11), 27482760. doi:10.1038/oby.2007.327

Hasnat, M., \& Graves, P. (2000). Disclosure of developmental disability: A study of parent satisfaction and the determinants of satisfaction. Journal of Paediatrics \& Child Health, 36(1), 32-35. doi:10.1046/j.1440-1754.2000.00463.x

Hodges, W., Landon, J., \& Colwell, J. (1990). Stress in parents and late elementary age children in divorced and intact families and child adjustment. Journal of Divorce and Remarriage, 14(1), 63-79. doi:10.1300/J087v14n01_06

Huang, M., Liu, C., Chi, Y., Huang, C., \& Cain, K. (2001). Parental concerns for the child with febrile convulsion: Long-term effects of educational interventions. Acta Neurologica Scandinavica, 103(5), 288-293. doi:10.1034/j.1600-0404.2001.103005288.x

Huppertz, H., Forster, J., Heininger, U., Roos, R., Neumann, H., \& Hammerschmidt, T. (2008). The parental appraisal of the morbidity of diarrhea in infants and toddlers (PAMODI) survey. Clinical Pediatrics, 47(4), 363-371. doi:10.1177/0009922807310933

Inan, M., Aydiner, C., Tokuc, B., Aksu, B., Ayvaz, S., Ayhan, S., ...Basaran, U. N. (2007). Factors associated with childhood constipation. Journal of Paediatrics \& Child Health, 43(10), 700706. doi:10.1111/j.1440-1754.2007.01165.x

Inan, M., Tokuc, B., Aydiner, C., Aksu, B., Oner, N., Basaran, U. N. (2008). Personal characteristics of enuretic children: An epidemiological study from South-East Europe. Urologia Internationalis, 81(1), 47-53. doi:10.1159/000137640

Irving, L., Wall, M., Neumark-Sztainer, D., \& Story, M. (2002). Steroid use among adolescents: Findings from Project EAT. Journal of Adolescent Health, 30(4, Suppl), 243-252. doi:10.1016/S1054-139X(01)00414-1

Jackson, M., Crawford, D., Campbell, K., \& Salmon, J. (2008). Are Parental Concerns About Children's Inactivity Warranted, and Are They Associated With a Supportive Home Environment? Research Quarterly for Exercise \& Sport, 79(3), 274-282.

Kaitz, M. (2007). Maternal concerns during early parenthood. Child: Care, Health \& Development, 33(6), 720-727. doi:10.1111/j.1365-2214.2007.00729.x

Kalesan, B., Stine, J., \& Alberg, A. (2006). The Joint Influence of Parental Modeling and Positive Parental Concern on Cigarette Smoking in Middle and High School Students. Journal of School Health, 76(8), 402-407. doi:10.1111/j.1746-1561.2006.00133.x.

Kanoy, K., \& Schroeder, C. (1993). Suggestions to parents about common behavior problems in a pediatric primary care office. In M. Roberts, G. Koocher, D. Routh \& D. Willis (Eds.), Readings in Pediatric Psychology. (pp. 317-332). New York, NY: Plenum Press.

Kempe, A., Daley, M. F., McCauley, M. M., Crane, L. A., Suh, C. A., Kennedy, A. M., ..., Dickinson, L. M. (2011). Prevalence of parental concerns about childhood vaccines: The experience of primary care physicians. American Journal of Preventive Medicine, 40(5), 548555. doi:10.1016/j.amepre.2010.12.025

Kiliç, B. G., Bilgiç, A., Gürkan, K., \& Aysev, A. (2007). Sociodemographic and clinical factors associated with compliance to methylphenidate treatment in children with attention deficit hyperactivity disorder. Turkish Journal of Psychiatry, 18(3), 207-213. 
Kloep, M., Hendry, L., Ingebrigtsen, J., Glendinning, A., \& Espnes, G. (2001). Young people in 'drinking' societies? Norwegian, Scottish and Swedish adolescents' perceptions of alcohol use. Health Education Research, 16(3), 279-291. doi:10.1093/her/16.3.279

Kulkarni, A. (2007). Assessment of mother and father concern in childhood hydrocephalus. Quality of Life Research, 16(9), 1501-1509. doi:10.1007/s11136-007-9258-5

Lampard, A., Byrne, S., Zubrick, S., \& Davis, E. (2008). Parents' concern about their children's weight. International Journal of Pediatric Obesity, 3(2), 84-92. doi:10.1080/17477160701832552

Leib, S., Liberatos, P., \& Edwards, K. (2011). Pediatricians' experience with and response to parental vaccine safety concerns and vaccine refusals: A Survey of Connecticut Pediatricians. Public Health Reports, 126(Suppl 2), 13-23.

Leung, C., McBride-Chang, C., \& Lai, B. (2004). Relations among maternal parenting style, academic competence, and life satisfaction in Chinese early adolescents. The Journal of Early Adolescence, 24(2), 113-143. doi:10.1177/0272431603262678

Likierman, M. (1987). The function of anger in human conflict. International Review of PsychoAnalysis, 14, 143-161.

Lindsay, G., \& Dockrell, J. (2004). Whose job is it? Parents' concerns about the needs of their children with language problems. Journal of Special Education, 37(4), 225-235.

Lucas, A., Betlloch, I., Planelles, M., Martínez, T., Pérez-Crespo, M., Mataix, J., \& Belinchón, I. (2007). Non-melanocytic benign skin tumors in children. American Journal of Clinical Dermatology, 8(6), 365-369.

Lynch, T. R., Wildman, B. G., \& Smucker, W. D. (1997). Parental disclosure of child psychosocial concerns: Relationship to physician identification and management. Journal of Family Practice, 44(3), 273-280.

Malhi, P., \& Singhi, P. (2002). Can parental concerns detect children with behavioral problems? Studia Psychologica, 44(4), 359-365.

Matthey, S. (2001). The Sleep and Settle Questionnaire for parents of infants: Psychometric properties. Journal of Paediatrics and Child Health, 37(5), 470-475. doi:10.1046/j.14401754.2001.00703.x

Mattsson, A., \& Gross, S. (1966). Social and behavioral studies on hemophilic children and their families. The Journal of Pediatrics, 68(6), 952-964.

McGinty, C. (2000). An investigation into aspects of the Mayo early language screening test. Child: Care, Health and Development, 26(2), 111-128. doi:10.1046/j.1365-2214.2000.00176.x

McIsaac, W., Coyte, P., Croxford, R., Asche, C., Friedberg, J., \& Feldman, W. (2000). Otolaryngologists' perceptions of the indications for tympanostomy tube insertion in children. Canadian Medical Association Journal, 162(9), 1285-1288.

McMahon, C., Malesa, E., Yoder, P., \& Stone, W. (2007). Parents of children with Autism Spectrum Disorders have merited concerns about their later-born infants. Research \& Practice for Persons with Severe Disabilities, 32(2), 154-160.

Mesibov, G., Schroeder, C., \& Wesson, L. (1993). Parental concerns about their children. In M. Roberts, G. Koocher, D. Routh \& D. Willis (Eds.), Readings in Pediatric Psychology. (pp. 307-316). New York, NY: Plenum Press.

Miljkovitch, R., Pierrehumbert, B., Karmaniola, A., Bader, M., \& Halfon, O. (2005). Assessing attachment cognitions and their associations with depression in youth with eating or drug misuse disorders. Substance Use \& Misuse, 40(5), 605-623. doi:10.1081/JA-200055349 


\section{PARENTAL CONCERNS DEFINITION}

Mitchell, R., Wake, M., Canterford, L., \& Williams, J. (2008). Does maternal concern about children's weight affect children's body size perception at the age of 6.5? A community-based study. International Journal of Obesity, 32(6), 1001-1007. doi:10.1038/ijo.2008.12

Mulhern, S., Dworkin, P., \& Bernstein, B. (1994). Do parental concerns predict a diagnosis of attention deficit-hyperactivity disorder (ADHD)? Journal of Developmental \& Behavioral Pediatrics, 15(5), 348-352.

Musher-Eizenman, D., Holub, S., Hauser, J., \& Young, K. (2007). The relationship between parents' anti-fat attitudes and restrictive feeding. Obesity, 15(8), 2095-2102. doi:10.1038/oby.2007.249

Oberklaid, F., Dworkin, P. H., \& Levine, M. D. (1979). Developmental-behavioral dysfunction in preschool children. Descriptive analysis of a pediatric consultative model. American Journal of Diseases of Children, 133(11), 1126-1131.

Olusanya, B., Eletu, O., Odusote, O., Somefun, A., \& Olude, O. (2006). Early detection of infant hearing loss: Current experiences of health professionals in a developing country. Acta Paediatrica, 95(10), 1300-1302. doi:10.1080/08035250600603016

Owens, J., \& Palermo, T. (2008). Introduction to the Special Issue: Sleep in children with neurodevelopmental and psychiatric disorders. Journal of Pediatric Psychology, 33(4), 335338. doi:1010.1093/jpepsy/jsn019

Peterson, D. R., Becker, W. C., Hellmer, L. A., Shoemaker, D. J., \& Quay, H. C. (1959). Parental attitudes and child adjustment. Child Development, 30(1), 119-130. doi:10.2307/1126135

Petousis-Harris, H., Goodyear-Smith, F., Turner, N., \& Soe, B. (2004). Family physician perspectives on barriers to childhood immunisation. Vaccine, 22(17/18), 2340-2344. doi:10.1016/j.vaccine.2003.10.037

Rannard, A., Lyons, C., Glenn, S. (2005). Parent concerns and professional responses: the case of specific language impairment. The British Journal of General Practice, 55(518), 710-714.

Regalado, M., \& Halfon, N. (2001). Primary care services promoting optimal child development from birth to age 3 years: review of the literature. Archives of Pediatrics \& Adolescent Medicine, 155(12), 1311-1322.

Reijneveld, S. A., de Meer, G., Wiefferink, C. H. \& Crone, M. R. (2008). Parents' concerns about children are highly prevalent but often not confirmed by child doctors and nurses. BMC Public Health, 8, 124. doi:10.1186/1471-2458-8-124

Restall, G., \& Borton, B. (2010). Parents' concerns about their children's development at school entry. Child: Care, Health \& Development, 36(2), 208-215. doi:10.1111/j.13652214.2009.01019.x

Richter, L. M. (2003). Poverty, underdevelopment and infant mental health. Journal of Paediatrics and Child Health, 39(4), 243-248. doi:10.1046/j.1440-1754.2003.00145.x

Ridgewell, C., Sipe, N., \& Buchanan, N. (2009). School travel modes: Factors influencing parental choice in four Brisbane schools. Urban Policy \& Research, 27(1), 43-57. doi:10.1080/08111140802304793

Sadeh, A., Flint-Ofir, E., Tirosh, T., \& Tikotzky, L. (2007). Infant sleep and parental sleep-related cognitions. Journal of Family Psychology, 21(1), 74-87. doi:10.1037/0893-3200.21.1.74

Samms-Vaughan, M., \& Franklyn-Banton, L. (2008). The role of early childhood professionals in the early identification of autistic disorder. International Journal of Early Years Education, 16(1), 75-84. doi:10.1080/09669760801892318

Seagull, F. N., Mowery, J. L., Simpson, P. M., Robinson, T. R., Martier, S. S., Sokol, R. J., \& McGarver-May, D. G. (1996). Maternal assessment of infant development: Associations with 
alcohol and drug use in pregnancy. Clinical Pediatrics, 35(12), 621-628. doi:10.1177/000992289603501203

Shevell, M., Majnemer, A., Rosenbaum, P., \& Abrahamowicz, M. (2001). Profile of referrals for early childhood developmental delay to ambulatory subspecialty clinics. Journal of Child Neurology, 16(9), 645-650. doi:10.1177/088307380101600904

Skeat, J., Eadie, P., Ukoumunne, O., \& Reilly, S. (2010). Predictors of parents seeking help or advice about children's communication development in the early years. Child: Care, Health and Development, 36(6), 878-887. doi:10.1111/j.1365-2214.2010.01093.x

Slater, A., Bowen, J., Corsini, N., Gardner, C., Golley, R., \& Noakes, M. (2010). Understanding parent concerns about children's diet, activity and weight status: an important step towards effective obesity prevention interventions. Public Health Nutrition, 13(8), 1221-1228. doi:10.1017/S1368980009992096

Soenens, B., Vansteenkiste, M., \& Luyten, P. (2010). Toward a domain-specific approach to the study of parental psychological control: Distinguishing between dependency-oriented and achievement-oriented psychological control. Journal of Personality, 78(1), 217-256. doi:10.1111/j.1467-6494.2009.00614.x

Stickler, G. B., Salter, M., Broughton, D. D., \& Alario, A. (1991). Parents' worries about children compared to actual risks. Clinical Pediatrics, 30(9), 522-528. doi:10.1177/000992289103000901

Stine, J. J. (1994). Psychosocial and psychodynamic issues affecting noncompliance with psychostimulant treatment. Journal of Child and Adolescent Psychopharmacology, 4(2), 7586. doi:10.1089/cap.1994.4.75

Stradmeijer, M., Bosch, J., Koops, W., \& Seidell, J. (2000). Family functioning and psychosocial adjustment in overweight youngsters. International Journal of Eating Disorders, 27(1), 110114. doi:10.1002/(SICI)1098-108X(200001)27:1<110::AID-EAT14>3.0.CO

Swain, J., Lorberbaum, J., Kose, S. \& Strathearn, L. (2007). Brain basis of early parent-infant interactions: psychology, physiology, and in vivo functional neuroimaging studies. Journal of Child Psychology \& Psychiatry, 48(3/4), 262-287. doi:10.1111/j.1469-7610.2007.01731.x

Thompson, M., \& Thompson, G. (1991). Early identification of hearing loss: Listen to parents. Clinical Pediatrics, 30(2), 77-80. doi:10.1177/000992289103000202

Timperio, A., Salmon, J., Telford, A., \& Crawford, D. (2005). Perceptions of local neighbourhood environments and their relationship to childhood overweight and obesity. International Journal of Obesity, 29(2), 170-175. doi:10.1038/sj.ijo.0802865

Tomlin, A. (2003). Infant Mental Health: Making a Difference. Professional Psychology: Research and Practice, 34(6), 617-625. doi:10.1037/0735-7028.34.6.617

Törnqvist, J., Van Broeck, N., Finkenauer, C., Rosati, R., Schwering, K., Hayez, J.,... Otte, J. (1999). Long-term psychosocial adjustment following pediatric liver transplantation. Pediatric Transplantation, 3(2), 115-125. doi:10.1034/j.1399-3046.1999.00026.x

Triggs, E. G., \& Perrin, E. C. (1989). Listening carefully: Improving communication about behavior and development: Recognizing parental concerns. Clinical Pediatrics, 28(4), 185-192. doi:10.1177/000992288902800407

Valkenburg, P., Krcmar, M., Peeters, A., \& Marseille, N. (1999). Developing a scale to assess three styles of television mediation: 'Instructive mediation,' 'restrictive mediation,' and 'social coviewing'. Journal of Broadcasting \& Electronic Media, 43(1), 52-66. doi:10.1080/08838159909364474

Vaughan, M. (2005). Parental concerns and well-being: A study of mothers of children with disabilities. Dissertation Abstracts International, 66(3-B), 1763. 


\section{PARENTAL CONCERNS DEFINITION}

Voigt, R., Johnson, S., Mellon, M., Hashikawa, A., Campeau, L., Williams, A., ...Juhn, Y. (2009). Relationship between parenting stress and concerns identified by developmental screening and their effects on parental medical care-seeking behavior. Clinical Pediatrics, 48(4), 362368. doi:10.1177/0009922808327058

Wake, M., Hardy, P., Sawyer, M., \& Carlin, J. (2008). Comorbities of overweight/obesity in Australian preschoolers: a cross-sectional population study. Archives of Disease in Childhood, 93(6), 502-507. doi:10.1136/adc.2007.128116

Wildman, B., Kizilbash, A., \& Smucker, W. (1999). Physicians' attention to parents' concems about the psychosocial functioning of their children. Archives of Family Medicine, 8, 440444.

Wildman, B., Stancin, T., Golden, C., \& Yerkey, T. (2004). Maternal distress, child behaviour, and disclosure of psychosocial concerns to a paediatrician. Child: Care, Health \& Development, 30(4), 385-394. doi:10.1111/j.1365-2214.2004.00428.x

Williams, J., Lange, B., Sharp, G., Griebel, M., Edgar, T., Haley, T.,...Dykman, R. (2000). Altered sleeping arrangements in pediatric patients with epilepsy. Clinical Pediatrics, 39(11), 635642. doi:10.1177/000992280003901102

Winnicott, D.W. (1979). The Maturational Processes and the Facilitating Environment. London: Tavistock.

Wissow, L., Wilson, M., Roter, D., Larson, S., \& Berman, H. (1992). Family violence and the evaluation of behavioral concerns in a pediatric primary care clinic. Medical Care, 30(5, Suppl), MS150-165.

Wren, F., Scholle, S., Heo, J., \& Comer, D. (2003). Pediatric mood and anxiety syndromes in primary care: Who gets identified. International Journal of Psychiatry in Medicine, 33(1), 116. doi:10.2190/UT6D-RDFG-LBT7-G39N

Zimmerman, J. A., Feigal, R. J., Till, M. J., \& Hodges, J. S. (2009). Parental attitudes on restorative materials as factors influencing current use in Pediatric Dentistry. Pediatric Dentistry, 31(1), 63-70. 